\title{
Cultural Consumption of the Overseas Chinese Garden in the Process of Cross-cultural Communication
}

\author{
Zhai Lian ${ }^{\text {a }}$ \\ ${ }^{a}$ Department of Architecture, SEU,210096, zhailian111@gmail.com
}

Keywords: Overseas Chinese garden; cross-cultural communication; cultural consumption

\section{ABS TRACT:}

When referring to the tangible cultural heritage, people tend to concern more about the conservation and research of the entity of the tangible heritage than the cross-cultural communication of the cultural heritage which is also one of the most important components of the preservation of the cultural heritage. As an exotic new born of the cultural heritage, the entity born from the cross-cultural communication inherits the properties of the cultural heritage on the one hand, and on the other hand generates diversities as a result of the differences based on social, cultural and environment. And the business model is one of the most important reasons for the production of diversities. There's no doubt that a good form of business model makes great significance to the cross-cultural communication. Therefore, the study of the business model of cultural heritage in the process of cross-cultural communication will not only contributes to the deeper understanding towards the phenomenon of the cultural heritage's cross-cultural communication, but also leads to the introspection to the tangible cultural heritage itself. In this way, a new kind of conservative notion could take form, and the goal of protecting cultural heritage could be achieved. Thus the Chinese Garden is a typical representation of the cultural heritage which makes great sense in the cross-cultural communication.

As a kind of tangible cultural heritage, the Chinese gardens are well preserved in different regions in China. While the spirits of the Chinese garden carry forward through the construction of the Chinese gardens abroad during the cross-cultural communication. As a new kind of form of the cross-cultural communication of the cultural heritage, on the one hand, the Chinese gardens overseas built ever since China's Reform and Opening express creatively of the materialist and the spirituality of the traditional Chinese Garden, and on the other hand, those Chinese gardens overseas face all kinds of tough issued such as investment, business model and management. The exploration of the reasons for these tough issues makes a great sense of the study towards the cross-cultural communication and preservation of the cultural heritage.

In this paper, the development of the whole overseas gardens and the cultural consumption of the Chinese gardens in Europe is generalized, then two typical cases are selected from those two categories mentioned above. By way of field study and interviews, it shows different strategies towards cultural consumption and provides constructive advice for the survival and development of overseas Chinese gardens.

\section{Introduction - - Overview of the Overseas Chinese Gardens} From $17^{\text {th }}$ to $18^{\text {th }}$ century, chinoiserie had been popular in Europe for about 200 years. In the late of $19^{\text {th }}$ century, this fascination with Chinese art declined as a result of the corruption of Qing dynasty. It was not until China’s Reform and Opening up in 1978 that Chinese gardens appeared on the world stage once again.

In the 1980s, the preoccupation with Chinese gardens once again took hold with the construction of "Ming Xuan" in the Metropolitan Museum of Art in New York. With more frequent exchanges between China and Europe, the Chinese gardens often sent as presents between sister cities or participated in international horticultural exhibitions. Now there are more than 50 gardens all over the world, distributed in a total of 17 countries. 20 of them are in Europe, located in Germany, Britain, France, Belgium, Netherland, Switzerland and, Malta. 
Chart 1, general information of the Overseas Chinese gardens in Europe built after 1978

(The grey part are the gardens contain consuming behavior. )

\begin{tabular}{|c|c|c|c|c|c|c|}
\hline $\begin{array}{l}\text { General } \\
\text { Types }\end{array}$ & $\begin{array}{l}\text { Motivation } \\
\text { for } \\
\text { Construction }\end{array}$ & Name & $\begin{array}{c}\text { Country } \\
\text { and Year of } \\
\text { Opening }\end{array}$ & $\begin{array}{c}\text { Manager and } \\
\text { Function }\end{array}$ & Usage and Consumption & $\begin{array}{c}\text { Cultural } \\
\text { Consuming } \\
\text { Types }\end{array}$ \\
\hline \multirow{9}{*}{$\begin{array}{l}\text { Chinese } \\
\text { gardens } \\
\text { exported } \\
\text { through the } \\
\text { process of } \\
\text { cross- } \\
\text { cultural } \\
\text { communicat } \\
\text { ion }\end{array}$} & \multirow[t]{8}{*}{$\begin{array}{l}\text { Garden as } \\
\text { present } \\
\text { between sister } \\
\text { cities }\end{array}$} & $\begin{array}{l}\text { 1. Chun } \\
\text { Hua } \\
\text { Garden }\end{array}$ & $\begin{array}{l}\text { Germany,19 } \\
89\end{array}$ & $\begin{array}{l}\text { 1.Managed by } \\
\text { government, } \\
\text { 2.free entrance } \\
\text { park }\end{array}$ & Non-profit, few tourists. & None \\
\hline & & $\begin{array}{l}\text { 2.Si Chuan } \\
\text { restaurant }\end{array}$ & $\begin{array}{l}\text { Austria, } \\
1989\end{array}$ & $\begin{array}{l}\text { 1.Managed by } \\
\text { personal, } \\
\text { 2.Restaurant }\end{array}$ & $\begin{array}{l}\text { From near bankruptcy to } \\
\text { successful op eration. }\end{array}$ & $\begin{array}{l}\text { Simple } \\
\text { cultural } \\
\text { consumption }\end{array}$ \\
\hline & & $\begin{array}{l}\text { 3.Qian } \\
\text { Yuan }\end{array}$ & $\begin{array}{l}\text { Germany,19 } \\
90\end{array}$ & $\begin{array}{l}\text { 1.Managed by } \\
\text { university, } \\
\text { 2.free entrance } \\
\text { park }\end{array}$ & $\begin{array}{l}\text { Non-profit, although } \\
\text { subject to geographical } \\
\text { restrictions, the garden } \\
\text { itself is very unique, and } \\
\text { attracts a lot of tourists. }\end{array}$ & None \\
\hline & & $\begin{array}{l}\text { 4.Chinese } \\
\text { garden }\end{array}$ & $\begin{array}{l}\text { Switzerland, } \\
1993\end{array}$ & $\begin{array}{l}\text { 1.Managed by } \\
\text { government, } 2 . \\
\text { Chargeable park }\end{array}$ & $\begin{array}{l}\text { has good location, but few } \\
\text { tourists. }\end{array}$ & $\begin{array}{l}\text { Simple cultural } \\
\text { consumption }\end{array}$ \\
\hline & & $\begin{array}{l}\text { 5.Garden } \\
\text { of Serenity }\end{array}$ & Malta,1997 & $\begin{array}{l}\text { 1.Managed by } \\
\text { government, } \\
\text { 2.free entrance } \\
\text { park }\end{array}$ & $\begin{array}{l}\text { Non-profit, subject to } \\
\text { geographical restrictions, } \\
\text { has few tourists }\end{array}$ & None \\
\hline & & $\begin{array}{l}\text { 6.De Yue } \\
\text { Garden }\end{array}$ & $\begin{array}{l}\text { Germany, } \\
2000\end{array}$ & $\begin{array}{l}\text { 1.Managed by } \\
\text { government, } 2 . \\
\text { Chargeable park }\end{array}$ & $\begin{array}{l}\text { attached to a larger park, } \\
\text { well-designed, has more } \\
\text { tourists. }\end{array}$ & $\begin{array}{l}\text { integral } \\
\text { cultural } \\
\text { consumption }\end{array}$ \\
\hline & & $\begin{array}{l}\text { 7.Yu } \\
\text { Garden }\end{array}$ & $\begin{array}{l}\text { Germany, } \\
2008\end{array}$ & $\begin{array}{l}\text { 1.Managed by } \\
\text { Shanghai Yu } \\
\text { Yuan company } \\
2 . \\
\text { Chargeable park }\end{array}$ & $\begin{array}{l}\text { Started with commercial } \\
\text { profit, bleak operation, } \\
\text { then bankruptcy. Now it } \\
\text { belongs to the Confucius } \\
\text { Institute. }\end{array}$ & $\begin{array}{l}\text { Simple cultural } \\
\text { consumption }\end{array}$ \\
\hline & & $\begin{array}{l}\text { 8.Gu su } \\
\text { garden }\end{array}$ & $\begin{array}{l}\text { Switzerland, } \\
2012\end{array}$ & Non-public & $\begin{array}{l}\text { Non-profit, few tourists, } \\
\text { belongs to WTO. }\end{array}$ & None \\
\hline & participate in & 9.Fang Hua & Germany, & 1.Managed by & Non-profit, large numbers & None \\
\hline
\end{tabular}




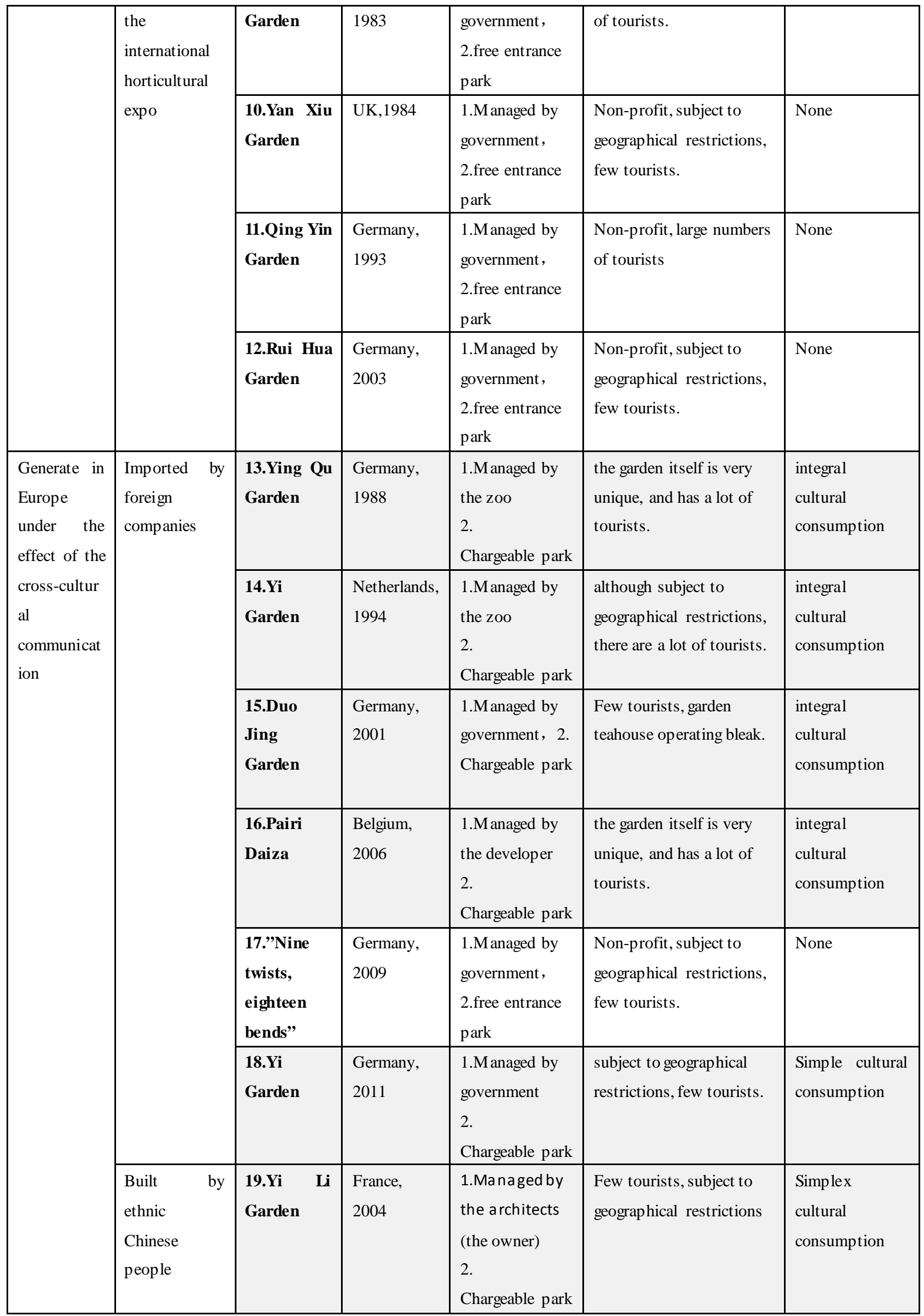




\section{The Usage and management Investigation of the Chinese Gardens in Europe}

The background of these gardens' construction is the advent of globalization and marketization. Although the reasons for construction of these gardens differ from one another, they can be generally divided into two types based on the motivation for construction: gardens exported from China to Europe, and gardens generated in Europe under the effect of the cross-cultural exchange. The former one contains two types: gardens sent as presents between sister cities in China and Europe, and gardens built to participate in international flower expositions. The latter one also contains two types: gardens invested and built by European companies, and gardens built by overseas Chinese.

Based on the investigation of the overseas Chinese gardens in Europe, the management and usage of these gardens is listed in Chart 1. The grey part shows gardens containing cultural consuming behavior, the rest are those with free entrance. From this chart, we can see that the gardens built to participate in international flower expositions have all free entrance at present, and gardens constructed out of marketization are mostly chargeable.

According to whether the consuming objects are the gardens themselves or not, the cultural consumption can be divided into two types: the integral one and the simple one. The integral type means that the Chinese garden is part of a larger one, such as a Chinese garden in a zoo, or a Chinese garden in a botanical garden. And the simple type means that the Chinese garden itself is the whole consuming object.

From Chart 1, it can be concluded that most of the gardens sent as presents from China to European sister cities belong to the simple consuming type and there are fewer visitors than expected. Most of the gardens originating in Europe are of the integral consuming type, and they have more visitors and are usually better designed. In general conclusion, the cultural consuming types have a close relationship with the gardens' design method and management, which affect the tourist numbers as a result.

Therefore, to some extent, the cultural consuming types determine the survival and development of the overseas Chinese gardens. And the cultural consuming types have close relationship with the design and management of the gardens. The tourists numbers and profit will probably be increased if the cultural consuming types is combined with the function and space of the gardens at the start of the project.
In additional, the tourists number doesn't have an inevitable relationship with the cultural consumption for many overseas Chinese gardens are free entrance. Some of them which are elaborately designed although located in remote areas still have a great number of tourists, such as the Qian Garden in Bochum, Germany. The non-profit Chinese gardens face no grim problem of existence for their funds come from local governments. Thus the design quality determines the tourists number; while for the chargeable Chinese gardens, the consideration for cultural consuming types directly determines the usage and tourists number in the future.

3. The Integral Cultural Consuming Type_taking example of Pairi Daiza (Figure 1)

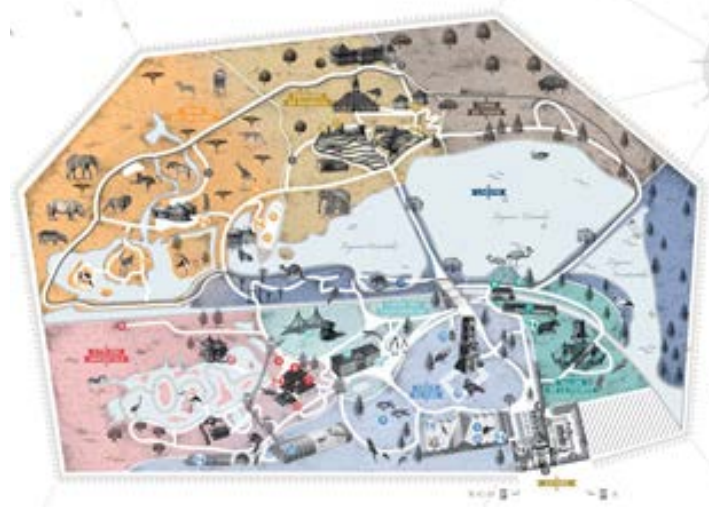

Figure 1.the site plan of Pairi Daiza

(Image source: http://www.pairidaiza.eu/en)

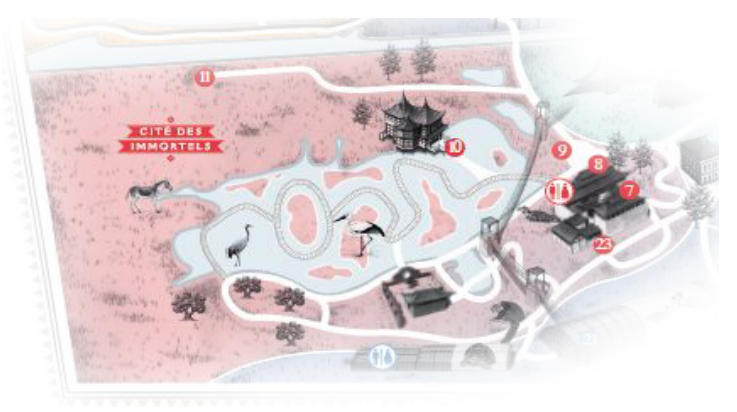

Figure 2. Site plan of the Chinesegarden in Pairi Daiza (Image source: http://www.pairidaiza.eu/en)

Chart 1 shows that most of the overseas Chinese gardens of the integral cultural consuming type enjoy high popularity. How can the integral cultural consuming type attract large number of tourists? What are the characteristics of the garden design? A typical case below shows the initial solution to these questions. 
The Pairi Daiza, meaning paradise in ancient Persia, is located $60 \mathrm{~km}$ away from Brussels, capital of Belgium. The Chinese garden (Figure 2) in this zoo was built in 2006, covers an area of $45,000 \mathrm{~m}^{2}$, and is considered the largest Chinese park in Europe. The design of this park mainly considers two questions: firstly, how to combine a Chinese garden with local Chinese animals, secondly, how to combine the Chinese garden with consuming activities.

The answer to the first question was to build a long zigzag corridor (Figure 3,4). The linear space of a corridor brings tourists with a sense of guidance, and the zigzag shape leads the tourists' sight to both sides of the corridor. Thus, the two sides become a perfect space for animals' exhibition. The long zigzag corridor covers almost half of the Chinese garden, which is rarely seen in traditional Chinese gardens, and the

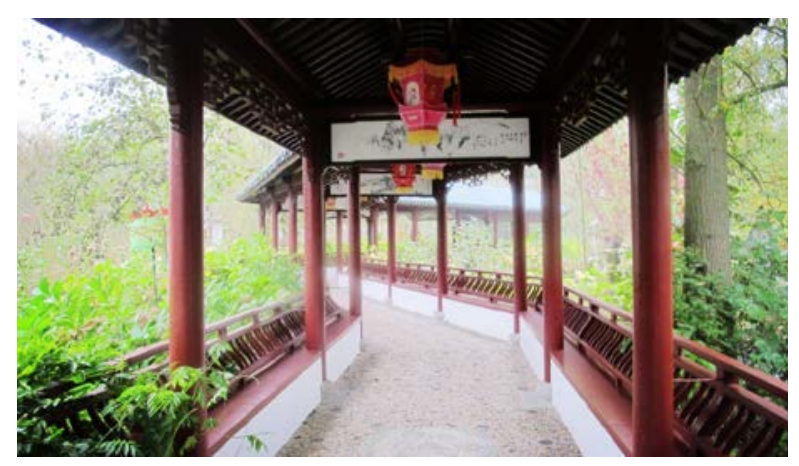

Figure 3.the long corridor in Pairi Daiza

(Image source: taken by the author )

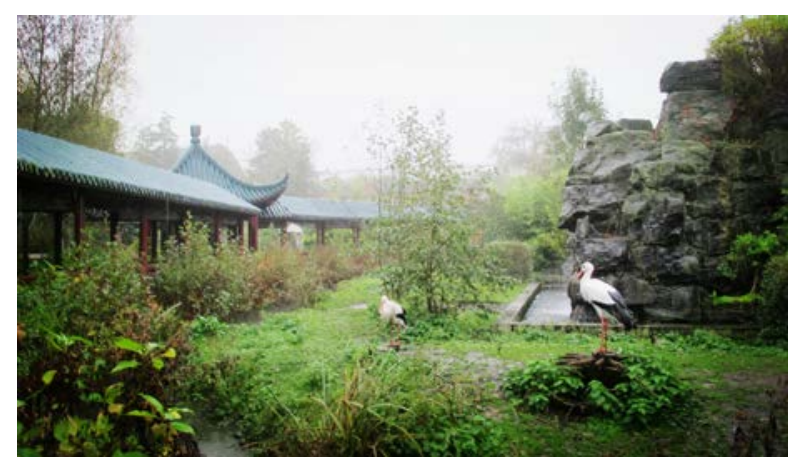

Figure 4.the animals in Pairi Daiza

(Image source: taken by the author)

design of combining corridor with local Chinese animals and plants is also scarce in modern landscape design.

The answer to the second question, how to combine the Chinese garden with consuming behavior, is to build some group buildings associated with courtyards, such as a teahouse (Figure 5), a footbath room and a Chinese restaurant. These buildings located at the entrance and existence of the Chinese garden.

From above we can see, most of the area has nothing to do with consuming behavior, but how could the zoo profit from these facilities? While the visitors are wandering in the zoo, they are immersed in the atmosphere which contains not only the animals, plants, but also all kinds of experiences. These integral activities increase the zoo's attractiveness and as a result

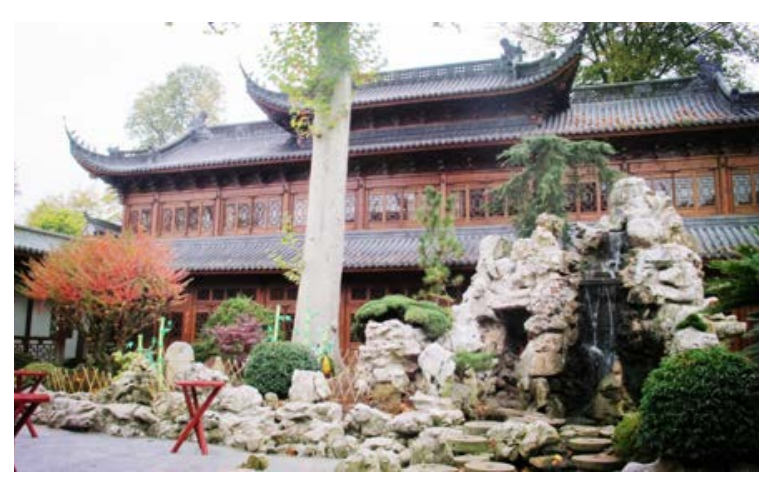

Figure 5.the tea house in Pairi Daiza

(Image source: taken by the author)

increase the tourists' number.

4. The Simplex Cultural Consuming Type _taking example of Yu Garden in Hamburg (Figure 6)

Chart 1 shows that most of the overseas Chinese gardens in simple cultural consuming type have little popularity and some of them are even gradually dying out. How did the simple cultural consuming type come into being? A typical case below shows the inherent characteristics of the simple cultural consuming type.

The Yu Garden in Hamburg, Germany was built up in 2008.

The motivation for construction was to build an arena for holding Chinese cultural activities. While the investment is from Yu Garden Company, a private company in shanghai, the garden had been seeking to make profit since its opening until 2013. In 2010, only 2 y ears after its completion, the Yu Garden in Hamburg was closed as a result of non-profitable earnings and building decay. It was not until 3 years later in 2013, that the Yu Garden in Hamburg was opened up again. This time it was managed and funded by the Confucius College in Hamburg University, and the outcome of the transformation remains to be seen.

Looking back to the process of this project, the choice of location had nothing to do with the designers: the government leader actually chose the site without any market survey. and 
the garden copied the original Yu Garden in Shanghai without further design changes. What's more, the function of the garden only consists of a tea house and a Chinese restaurant, which has no connection with its environment. From this case, we can find that the simplex cultural consuming type is essentially kind of a static, isolated operation system, which cannot build up an interactive relationship with consumers, and the social environment, therefore, it descends to a symbol which nobody cares about at last.

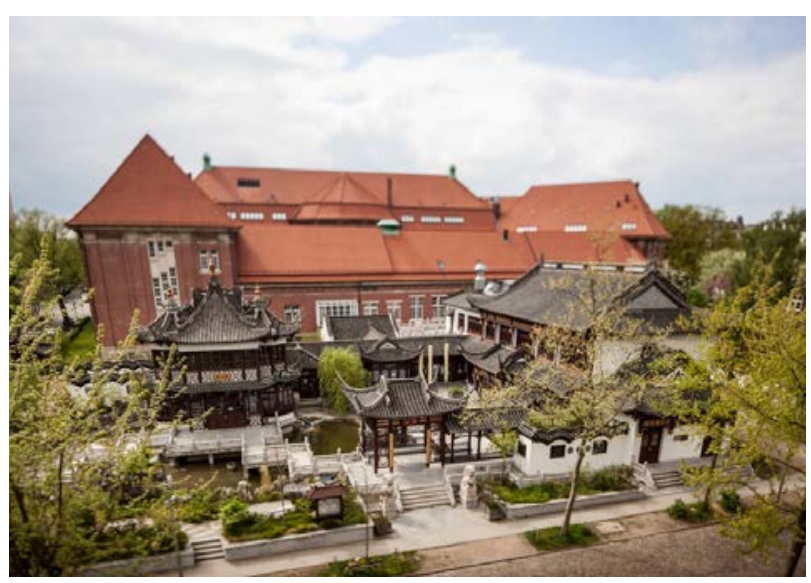

Figure 6. Yu Garden in Hamburg

(Image source:

https://www.facebook.com/hamburg.yugarden?fref=ts )

\section{Conclusion}

From the comparison of these two cases, the differences between the two types of cultural consumption can be concluded as follows (chart 2). In conclusion, overseas Chinese gardens can be divided into two types according to the motivation of construction: gardens exported from China to Europe, and gardens originating in Europe themselves. According to whether the consuming objects are the gardens themselves, the cultural consumption type can be divided into the integral one and the simple one. From the investigation, I am drawing the conclusion that most of the gardens exported from China to Europe are of the simple cultural consumption type, and most of the gardens generated in Europe are of the integral cultural consumption type.

According to this conclusion, we can give some recommendations regarding the development of overseas Chinese gardens: firstly, the design of the gardens should associate the garden with its social and cultural environment, combined with the consideration of the atmosphere, people's behavior and so on. Secondly, as the gardens exported from China to Europe are not a direct production of the marketing operation, they are always filled with the subjective wishes of the exporters. So the gardens exported from China to Europe should avoid taking Chinese private companies as investors. Thirdly, If the investor is a domestic private company, market investigation and elaborated integral cultural consuming design is strongly recommended.

Chart 2. Comparison between two kinds of cultural consumption types

\begin{tabular}{|c|c|c|}
\hline & $\begin{array}{l}\text { Type of Integral } \\
\text { Cultural } \\
\text { Consumption }\end{array}$ & $\begin{array}{c}\text { Type of Simple } \\
\text { Cultural } \\
\text { Consumption }\end{array}$ \\
\hline $\begin{array}{l}\text { Motivation } \\
\text { for } \\
\text { Construction }\end{array}$ & $\begin{array}{l}\text { Market } \\
\text { Requirement }\end{array}$ & $\begin{array}{l}\text { Cross-cultural } \\
\text { communication }\end{array}$ \\
\hline Investor & $\begin{array}{l}\text { Companies } \\
\text { abroad }\end{array}$ & Domestic companies \\
\hline Site & $\begin{array}{l}\text { The site is } \\
\text { determined by the } \\
\text { investor and } \\
\text { designer, } \\
\text { according to the } \\
\text { action, demand } \\
\text { and the results of } \\
\text { investigation. }\end{array}$ & $\begin{array}{l}\text { The site is determined } \\
\text { by the official leader } \\
\text { instead of the designer, } \\
\text { which results in the } \\
\text { isolation of the garden. }\end{array}$ \\
\hline Function & $\begin{array}{l}\text { Compound } \\
\text { function suit to } \\
\text { the demand }\end{array}$ & Single function \\
\hline Space & $\begin{array}{l}\text { Space is related to } \\
\text { function, leading } \\
\text { to the experience } \\
\text { out of expectation }\end{array}$ & $\begin{array}{l}\text { Generally copy from } \\
\text { domestic Chinese } \\
\text { gardens }\end{array}$ \\
\hline $\begin{array}{c}\text { The quality } \\
\text { of } \\
\text { construction }\end{array}$ & High quality & Low quality \\
\hline $\begin{array}{l}\text { Adaptation } \\
\text { to cultural } \\
\text { environment }\end{array}$ & High & Low \\
\hline
\end{tabular}


The International Archives of the Photogrammetry, Remote Sensing and Spatial Information Sciences, Volume XL-5/W7, 2015 25th International CIPA Symposium 2015, 31 August - 04 September 2015, Taipei, Taiwan

\section{References:}

Liu Shaozong 1999. Excellent works of Chinese garden design (Overseas ) [M]. Chinese Architectural Industrial Press.

Gan Weilin. 2000. Cultural envoys - the Chinese gardens overseas [M] Chinese Architectural Industrial Press.

Liu Xiaoping. 2011. Architectural thinking in the context of cross-cultural communication [M] Chinese Architectural Industrial Press.

\section{Relatedwebsite:}

http://www.pairidaiza.eu/en

http://www.yu-garden.de/

http://finance.sina.com.cn/chanjing/gsnews/20111110/0103107

85811.shtml

https://www.facebook.com/hamburg.yugarden?fref=ts 